\title{
Livelihood Problems of Small and Marginal Farm Families in Rural Areas of Haryana State, India
}

\author{
Raman Jodha* and Manju Dahiya \\ Extension Education and Communication Management Department, \\ CCS Haryana Agricultural University, Hisar, Haryana, India \\ *Corresponding author
}

Keywords

Livelihood,

Security, Problems,

Poverty, Small, Marginal

Article Info

Accepted:

12 December 2017

Available Online:

10 January 2018

\section{A B S T R A C T}

Agriculture plays a pivotal role in the Indian economy. The economic reforms did not include any specific package specifically designed for agriculture which showed low growth, poverty, unemployment, inequalities in access to health and education and poor performance of agriculture sector and experienced more farmers' suicides. It may be noted that Indian agriculture is the home of small and marginal farmers. Therefore, the future of sustainable agriculture growth and food security in India depends on the performance of small and marginal farmers. There are also concerns on food security and livelihoods. The study was conducted in Gurgaon division of Haryana state and two districts from Gurgaon division i.e. Rewari and Mahendragarh were selected randomly. From selected two blocks Jatusana and Kanina, four villages (two from each block) Dahina and Maseet from Jatusana and Kakrala and Rambas from Kanina were selected randomly. From the selected villages a sample of 75 small and marginal farm families from was drawn randomly to make the total sample size of 300 farm families. In the study problems faced by farm families related to livelihood security was assessed and in Rewari district sample households highly faced problems related to climate (Rank I, WMS 2.24) followed by problems related to government (Rank II, WMS 2.08), problems related to household (Rank III and WMS 2.03), problems related to agriculture (Rank IV and WMS 1.98) and problems related to climate (Rank V, WMS 2.24) respectively.

\section{Introduction}

In India small farms have been the mainstay for food security and labour employment in India. Despite their significance in providing food security, family labour employment and economy in management and high productivity per acre, small farms face a few challenges particularly in the wake of globalization and WTO dispensation. The livelihood of the people is also vulnerable and at risk. Vulnerability and risk can be related to the type of crops cultivated. Both perennial and annual crops (e.g. bajra) are susceptible to dry conditions. The recurrent drought also reduces the yield or destroys the crop. The price of crop is unpredictable. Risk can also be related to food entitlement (Maxwell and Frankenberger, 1992). The risk of livelihood failure determines the level of vulnerability of a household to income, food, health and nutritional insecurity. The greater the share of 
resources devoted to food and health service acquisition, the higher the vulnerability of the household to food and nutritional insecurity. Therefore, livelihoods are secure when households have secure ownership of, or access to, resources (both tangible and intangible) and income earning activities, including reserves and assets, to off-set risks, ease shocks, and meet contingencies. Households have secure livelihoods when they are able to acquire, protect, develop, utilize, exchange, and benefit from assets and resources. Hence, in this study, an attempt was made to delineate the problems faced by farm families related to livelihood security.

\section{Materials and Methods}

The study was conducted in Haryana state and it has been divided into four division- Hisar division, Rohtak division, Ambala division and Gurgaon division. The present study was conducted in Gurgaon division which comprises Faridabad, Gurgaon, Mahendragarh, Mewat, Palwal, Rewari district. sarojsarojsar. Out of five districts, two districts from Gurgaon division i.e Rewari and Mahendragarh were selected randomly.

One block from each district viz., Jatusana block from Rewari district and Kanina block from Mahendergarh district, were selected randomly. From selected two blocks Jatusana and Kanina, four villages (two from each block) Dahina and Maseet from Jatusana and Kakrala and Rambas from Kanina were selected randomly. From the selected villages a sample of 75 small and marginal farm families from was drawn randomly. Thus a total of 300 respondents were selected randomly. Data was collected with the help of pre -structured interview schedule by the investigator from head of household of farm families. Statistical tools frequency, Percentages, weighted mean scores and ranking were applied for data analysis.

\section{Results and Discussion}

Socio-personal profile with respect to age, head of household, education of respondents, caste, marital status, family type, family size have been presented in Table 1 . Results shows that 57.67 per cent of the respondents belonged to the age group of 35-50 years followed by above 50 years $(30.00 \%)$ and below 35 years $(12.33 \%)$ respectively. As regards head of household, it was found that a large population of households $(96.67 \%)$ were headed by males and only 3.33 percent were headed by female. Regarding education of the respondents, it was noted that 41.67 per cent of the respondents were educated up to secondary followed by up to primary graduate $(33.33 \%)$, illiterate $(15.00 \%)$ and graduate \& above $(10.33 \%)$.With regard to caste of the respondents, it was found that more than half of the respondents $(52.33 \%)$ belonged to OBC caste in the both districts (Rewari and Mahendargarh) followed by general caste (23.3\%) and SC/ST caste (20.67). Similar findings were reported by Yadav (2016). The data in Table 1 clearly point out that in both districts (Rewari and Mahendargarh) majority of the respondents were married $(94.00 \%$ and $96.00 \%)$ respectively. In Rewari district 4.67 per cent and in Mahendargarh district 1.33 per cent respondents were unmarried. Only 2.00 percent respondents were widow/ widower. The same trend was observed in pooled sample. Regarding type of families it was observed that more than half of the respondents $(63.00 \%)$ belonged to joint families and 37.00 percent had nuclear families. Similar results were reported by Tayal (2012). It is clear from the data presented in Table 2 that in Problems related to agriculture viz., 'Small size of land' ranked first problem with highest weighted mean score (2.36), 'High labour cost' ranked second major problem with the weighted mean score (2.27) and 'High cost of inputs' ranked third problem with the weighted mean score (2.05). 
Table.1 Socio-personal profile of respondents

\begin{tabular}{|c|c|c|c|c|c|c|c|}
\hline \multirow[t]{2}{*}{$\begin{array}{l}\text { Sr. } \\
\text { No. }\end{array}$} & \multirow[t]{2}{*}{$\begin{array}{l}\text { Variables and } \\
\text { category }\end{array}$} & \multicolumn{2}{|c|}{ Rewari $(n=150)$} & \multicolumn{2}{|c|}{$\begin{array}{l}\text { Mahendergarh } \\
(\mathrm{n}=150)\end{array}$} & \multicolumn{2}{|c|}{ Total $(n=300)$} \\
\hline & & $\mathbf{F}$ & $\%$ & $\mathbf{F}$ & $\%$ & $\mathbf{F}$ & $\%$ \\
\hline \multirow[t]{4}{*}{1.} & \multicolumn{7}{|l|}{ Age } \\
\hline & Below 35 years & 12 & 8.0 & 25 & 16.67 & 37 & 12.33 \\
\hline & $35-50$ years & 82 & 54.67 & 91 & 60.67 & 173 & 57.67 \\
\hline & Above 50 years & 56 & 37.3 & 34 & 22.66 & 90 & 30.00 \\
\hline \multirow[t]{3}{*}{2.} & \multicolumn{7}{|c|}{ Head of Household } \\
\hline & Male & 147 & 98.00 & 143 & 95.33 & 290 & 96.67 \\
\hline & Female & 3 & 2.00 & 7 & 4.67 & 10 & 3.33 \\
\hline \multirow[t]{5}{*}{3.} & \multicolumn{7}{|c|}{ Education of respondent } \\
\hline & Illiterate & 21 & 14.0 & 23 & 15.33 & 44 & 15.00 \\
\hline & Up to primary & 64 & 42.67 & 36 & 24.00 & 100 & 33.33 \\
\hline & Up to secondary & 54 & 36.00 & 71 & 47.33 & 125 & 41.67 \\
\hline & $\begin{array}{l}\text { Graduate and } \\
\text { above }\end{array}$ & 11 & 7.3 & 20 & 13.33 & 31 & 10.33 \\
\hline \multirow[t]{4}{*}{4.} & \multicolumn{7}{|l|}{ Caste } \\
\hline & SC/ST & 29 & 19.33 & 33 & 22.00 & 62 & 20.66 \\
\hline & $\mathrm{OBC}$ & 80 & 53.33 & 77 & 51.33 & 157 & 52.33 \\
\hline & General & 41 & 27.33 & 40 & 26.67 & 81 & 27.00 \\
\hline \multirow[t]{4}{*}{5.} & \multicolumn{7}{|l|}{ Marital status } \\
\hline & Married & 141 & 94.00 & 144 & 96.00 & 285 & 95.00 \\
\hline & Unmarried & 7 & 4.67 & 2 & 1.33 & 9 & 3.00 \\
\hline & $\begin{array}{l}\text { Widow/ } \\
\text { Widower }\end{array}$ & 2 & 1.33 & 4 & 2.67 & 6 & 2.00 \\
\hline \multirow[t]{3}{*}{6.} & \multicolumn{7}{|l|}{ Type of family } \\
\hline & Joint & 107 & 71.33 & 82 & 54.67 & 189 & 63.00 \\
\hline & Nuclear & 43 & 28.67 & 68 & 45.33 & 111 & 37.00 \\
\hline
\end{tabular}


Table.2 Livelihood problems faced by farm families in Rewari District $(n=150)$

\begin{tabular}{|c|c|c|c|c|c|c|c|c|}
\hline \multirow{2}{*}{$\begin{array}{l}\text { Sr. } \\
\text { No. }\end{array}$} & \multirow[t]{2}{*}{ Category } & \multicolumn{7}{|l|}{ Rewari } \\
\hline & & Always (3) & $\begin{array}{l}\text { Sometimes } \\
\text { (2) }\end{array}$ & Never (1) & $\begin{array}{l}\text { Weighted } \\
\text { frequency } \\
\text { score }\end{array}$ & $\begin{array}{l}\text { Weighte } \\
\text { d mean }\end{array}$ & Rank & $\begin{array}{c}\text { Average } \\
\text { weighted } \\
\text { mean }\end{array}$ \\
\hline \multirow[t]{9}{*}{1.} & \multicolumn{8}{|l|}{ Problems related to agriculture } \\
\hline & Small size of land & $83(55.33)$ & $38(25.33)$ & $29(19.33)$ & 354 & 2.36 & I & \multirow[t]{8}{*}{1.98} \\
\hline & Pest infestation & $43(28.67)$ & $67(44.67)$ & $40(26.67)$ & 303 & 2.02 & IV & \\
\hline & Lack of farm implements & $39(26.00)$ & $63(42.00)$ & $48(32.00)$ & 291 & 1.94 & V & \\
\hline & Small size of land & $58(38.67)$ & $75(50.00)$ & $17(11.33)$ & 341 & 2.27 & II & \\
\hline & High production cost & $38(25.33)$ & $53(35.33)$ & $59(39.33)$ & 279 & 1.86 & VI & \\
\hline & Post-harvest losses & $33(22.00)$ & $56(37.33)$ & $61(40.67)$ & 272 & 1.81 & VII & \\
\hline & High cost of inputs & $48(32.00)$ & $61(40.67)$ & $41(27.33)$ & 307 & 2.05 & III & \\
\hline & Low productivity of livestock & $17(11.33)$ & $42(28.67)$ & $90(60.00)$ & 227 & 1.51 & VIII & \\
\hline \multirow[t]{7}{*}{2.} & \multicolumn{8}{|l|}{ Related to household } \\
\hline & Lack of capital & $134(89.33)$ & $16(10.67)$ & 0.0 & 434 & 2.89 & I & \multirow[t]{6}{*}{2.03} \\
\hline & Large family size & $21(14.00)$ & $53(35.33)$ & $76(50.67)$ & 245 & 1.63 & VI & \\
\hline & Occurrence of illness & $5(3.33)$ & $133(88.67)$ & $12(8.00)$ & 293 & 1.95 & III & \\
\hline & Poor access to resources & $31(20.67)$ & $69(46.00)$ & $50(33.33)$ & 281 & 1.87 & IV & \\
\hline & Low education & $36(24.00)$ & $79(52.67)$ & $35(23.33)$ & 301 & 2.01 & II & \\
\hline & Lack of skills & $28(18.67)$ & $71(47.33)$ & $51(34.00)$ & 277 & 1.85 & $\mathrm{~V}$ & \\
\hline \multirow[t]{6}{*}{3.} & \multicolumn{8}{|l|}{ Related to government } \\
\hline & $\begin{array}{l}\text { Broadcasting time of } \\
\text { agricultural program is not } \\
\text { suitable }\end{array}$ & $47(31.43)$ & $63(42.00)$ & $40(26.67)$ & 307 & 2.05 & III & \multirow[t]{5}{*}{2.08} \\
\hline & $\begin{array}{l}\text { Poor access to Extension } \\
\text { workers }\end{array}$ & $23(15.33)$ & $42(28.00)$ & $85(56.67)$ & 238 & 1.59 & IV & \\
\hline & Lack of cold storage facilities & $59(39.33)$ & $72(48.00)$ & $19(12.67)$ & 340 & 2.27 & II & \\
\hline & No timely procurement & $52(34.67)$ & $68(45.33)$ & $30(20.0)$ & 322 & 2.15 & $\mathrm{~V}$ & \\
\hline & Low support price & $63(42.00)$ & $73(48.67)$ & $14(9.33)$ & 349 & 2.33 & I & \\
\hline 4. & \multicolumn{8}{|l|}{ Related to market } \\
\hline & Poor access to market & $37(24.67)$ & $59(39.33)$ & $54(36.00)$ & 283 & 1.89 & II & \multirow[t]{3}{*}{1.89} \\
\hline & $\begin{array}{l}\text { Lack of improved seeds and } \\
\text { fertilizers }\end{array}$ & $24(16.00)$ & $72(48.00)$ & $54(36.00)$ & 270 & 1.80 & III & \\
\hline & Price fluctuation of outputs & $43(28.67)$ & $60(40.00)$ & $47(31.33)$ & 296 & 1.97 & I & \\
\hline \multirow[t]{6}{*}{5.} & Related to climate & & & & & & & \\
\hline & Low rainfall & $58(38.67)$ & $71(47.33)$ & $21(14.00)$ & 337 & 2.25 & III & \multirow[t]{5}{*}{2.24} \\
\hline & Declining soil fertility & $90(60.00)$ & $54(36.00)$ & $6(4.00)$ & 384 & 2.56 & II & \\
\hline & $\begin{array}{l}\text { Crop damage by late heavy } \\
\text { rain }\end{array}$ & $22(14.67)$ & $41(27.33)$ & $87(58.00)$ & 235 & 1.57 & V & \\
\hline & $\begin{array}{l}\text { Unavailability of natural } \\
\text { water bodies (e.g. canals, } \\
\text { rivers) }\end{array}$ & $98(65.33)$ & $52(34.67)$ & - & 398 & 2.65 & I & \\
\hline & $\begin{array}{l}\text { Crop yield reduction due to } \\
\text { drought effect }\end{array}$ & $54(36.00)$ & $69(46.00)$ & $27(18.00)$ & 327 & 2.18 & IV & \\
\hline
\end{tabular}


It is also concluded that in problems related to household viz., 'Lack of capital' ranked first problem with highest weighted mean score (2.89), 'low education' ranked second major problem with the weighted mean score (2.01) and 'Occurrence of illness' ranked third problem with the weighted mean score (1.95). In problem related to government viz., 'Low support price' ranked first problem with highest weighted mean score (2.33), 'Lack of cold storage facilities' ranked second major problem with the weighted mean score (2.27) and 'Broadcasting time of agricultural program is not suitable' ranked third problem with the weighted mean score (2.05). The findings of the study are similar with those Hegde (2013), Hogarth et al., (2013) and Kumar (2013).

Problem related to market viz., 'Price fluctuation of outputs' ranked first problem with highest weighted mean score (1.97), 'Poor access to market' ranked second major problem with the weighted mean score (1.89) and 'Lack of improved seeds and fertilizers' ranked third problem with the weighted mean score (1.80). Table 2 further indicated that problem related to climate viz., Unavailability of natural water bodies (e.g. canals, rivers)' ranked first problem with highest weighted mean score (2.65), Declining soil fertility ranked second major problem with the weighted mean score (2.56) and 'Low rainfall' ranked third problem with the weighted mean score (2.25) respectively. The findings of the study are similar with those of Papola (2010), Van den Berg (2010) and Singh (2011).

Table further depict that on the basis of average weighted mean score and ranks, in Rewari district sample households highly faced problems related to climate (Rank I, WMS 2.24) followed by problems related to government (Rank II, WMS 2.08), problems related to household (Rank III and WMS
2.03), problems related to agriculture (Rank IV and WMS 1.98) and problems related to climate (Rank V, WMS 2.24) respectively. The findings of the study are in accordance with those of Acharya (2006), Babulo et al., (2008), Chadha (2008) and Kumar et al., (2014).

Livelihoods can be made up of a range of onfarm and off-farm activities that together provide a variety of procurement strategies for food and cash. Thus, each household can have several possible sources of entitlement, which constitute its livelihood. Therefore, livelihoods are secure when households have secure ownership of, or access to, resources (both tangible and intangible) and income earning activities, including reserves and assets, to off-set risks, ease shocks, and meet contingencies. It is also concluded that in problems related to household viz., 'Lack of capital' ranked first problem with highest weighted mean score (2.89), 'low education' ranked second major problem with the weighted mean score (2.01). And in problem related to market viz., 'Price fluctuation of outputs' ranked first problem with highest weighted mean score (1.97), 'Poor access to market' ranked second major problem with the weighted mean score (1.89) and 'Lack of improved seeds and fertilizers' ranked third problem with the weighted mean score (1.80). So the government policies and programmes should be focused on small/marginal farmers and non-farm labourers and should made available employment opportunities which will increase their capabilities in term of income level, livelihood security and standard of living in rural areas.

\section{References}

Acharya, S.S., 2006. Sustainable Agriculture and Rural Livelihoods, Agricultural Economics Research Review Shyam S. Salim et al., Rural Livelihood Security: 
Assessment of Fishers' Social Status in India, Agricultural Economics Research Review, Vol. 26, 2013 pp 21-30.

Babulo, B., Muys, B., Nega, F., Tollens, E., Nyssen, J., Deckers, J., Mathijs, E., 2008. Household livelihood strategies and forest dependence in the highlands ofTigray, Northern Ethiopia. Agric. Syst. $98,147-155$.

Chadha, G.K. 2008. Employment and poverty in rural india: which way to go now, ILO Asia-Pacific Working Paper Series, ILO-SRO, New Delhi.

Frankenberger, T., Drinkwater, M. and Maxwell, D., 2000. Operationalizing household livelihood security: A holistic approach for addressing poverty and vulnerability Program Document, CARE USA.

Hegde, N.G. 2013. Mixed farming for sustainable livelihood of small farmers in India, paper presented at International Conference on Increasing Agricultural Productivity and Sustainability in India: The Future We Want, organised by National Institute of Advanced Studies (NIAS), in collaboration with M.S. Swaminathan Foundation, Chennai, Indian Institute of Science Campus, Bangalore. Jan 8-9.

Hogarth, N.J., Belcher, B., Campbell, B., Stacey, N., 2013. The role of forestrelated income in household economies and rural livelihoods in the borderregion of Southern China. World Dev.
$43,111-123$.

Kumar, A., 2013. Income and Livelihood Issues of Farmers: A Field Study in Uttar Pradesh, Agricultural Economics Research Review, Vol. 26: 89-96.

Kumar, P., Lakra, K., Bairwal, S.L., Kushwaha, S., 2014. Sustainable agriculture and rural livelihood security in India, Journal of Science Agriculture, Vol 4.

Papola, T.S. 2010. Livelihoods in Agriculture: Status, Policies and Prospects, State of India's Livelihood Report, edited by Sankar Datta and Vipin Sharma ; An ACCESS Publication, Sage Publications, New Delhi.

Singh, A. K., 2011. Agrarian change, nonfarm employment and poverty in India In: Agriculture for Inclusive Growth, Ed: Suresh Pal. Indian Agricultural Research Institute, New Delhi.

Tayal, S. 2012.Feasibility of vermicomposting as an enterprise for rural women. M.Sc. Thesis, CCS Haryana Agricultural University, Hisar, Haryana

Van den Berg, M., 2010. Household income strategies and natural disasters: dynamic livelihoods in rural Nicaragua. Ecol. Econ. 69, 592-602.

Yadav, R. 2016. Acceptability of Technical Knowledge on Cotton Cultivation through Media in Haryana. Ph.D. Thesis, CCS Haryana Agricultural University, Hisar, Haryana

\section{How to cite this article:}

Raman Jodha and Manju Dahiya. 2018. Livelihood Problems of Small and Marginal Farm Families in Rural Areas of Haryana State. Int.J.Curr.Microbiol.App.Sci. 7(01): 1624-1629. doi: https://doi.org/10.20546/ijcmas.2018.701.197 